N.V.Stukalo ${ }^{1}$, orcid.org/0000-0003-0517-1653, M.V. Lytvyn ${ }^{2}$, orcid.org/0000-0001-8597-6835, Y. M.Petrushenko ${ }^{3}$, orcid.org/0000-0001-9902-7577, Y. I. Pylypenko ${ }^{2}$, orcid.org/0000-0002-4772-1492, L. B. Kolinets ${ }^{3}$, orcid.org/0000-0002-7005-0519
1 - National Agency for Higher Education Quality Assurance, Kyiv, Ukraine

2 - Dnipro University of Technology, Dnipro, Ukraine, email: maryna lytvyn@ukr.net

3 - Sumy State University, Sumy, Ukraine

4 - West Ukrainian National University, Ternopil, Ukraine

\title{
THE CONCEPT OF SUSTAINABLE DEVELOPMENT OF UKRAINE IN THE CONTEXT OF GLOBAL THREATS
}

Purpose. To create the concept of sustainable development of Ukraine in the context of global threats.

Methodology. The research is based on the analysis of the components of integrated indicators and the formation of indicators based on them, which allow assessing the state of balance of socio-economic development of the national economy and determining the directions of corrective policy. In addition, the systematic approach is used to obtain the scientific results, which allowed us to consider the socio-economic development of society as the polysystem phenomenon, comparative analysis, statistical methods - in comparing the situation of Ukraine with other countries, logical analysis - in justifying and developing the concept of sustainable development of Ukraine in the context of globalization.

Findings. The concept of sustainable development of Ukraine has been developed, which is aimed at forming the new format of social relations and the new model of economy to increase the resilience of the national economy to global threats. The components of the Sustainable Development Index were analyzed and the comparative analysis of the components of global threats to Ukraine and other countries was made. It has been determined that the most dangerous challenges for Ukraine at the present stage are the high prevalence of morbidity among the population, high infant mortality, corruption, low energy security and inefficient public administration. It has been offered that the main purpose of the concept of sustainable development of Ukraine is to create conditions for overcoming existing threats. This requires the creation of a new form of government, a new format of public relations and a new economic model. The directions of achieving the main goals of sustainable development in Ukraine have been developed: social justice, balanced economic growth, ensuring high quality of the environment, rational use of resources, demographic stability and mutually beneficial international cooperation.

Originality. The authors' concept of sustainable development of Ukraine is based on ensuring the ability of the national economy to take advantage of the positive external effects of globalization and thereby reduce its negative impact on society. Stages have been established. The necessity has been substantiated of introduction of consistent and interconnected measures which are aimed at changing the quality of socio-economic development of the country on the basis of using mainly intensive factors of economic growth, introduction of environmentally friendly methods of economic activity, ensuring implementation of sustainable development in the context of overcoming multidimensional poverty life expectancy, the formation of the effective system of social assistance and health care. It has been determined that the implementation of these measures will ensure the formation of the new format of social relations and the new model of economy, as well as achievement of the Sustainable Development Goals.

Practical value. The results of the study can be used by national governments to develop the sustainable development policy, as well as by companies to operate their economic activity in the globalized space.

Keywords: sustainable development, global threats, globalization

Introduction. The research on the sustainable development problems is especially relevant at the present stage of the world economy. Although the 2030 Agenda [1] involves world resources, economic and social growth is a priority for each country, as it was emphasized in national policies and strategies. Ukraine is no exception; it has all the reasons to achieve balanced development. However, it is necessary to mention that there is a rather irrational structure of nature management because of previous economic activity in Ukraine, which is a consequence of decades-long accumulation of structural deformations of the economy, dominance of nature-intensive industries, resource and energy-intensive technologies, natural resources, raw material export orientation, excessive concentration of production in some regions of the state. The structure of the economy remains inefficient and environmentally dangerous. Depreciation of fixed assets, which in some industries reaches $90 \%$, is the cause of low economic efficiency of production, high energy, resource and financial costs, which determines the low quality of products and their competitiveness. Due to the low technological level of production,

(C) Stukalo N.V., Lytvyn M.V., Petrushenko Y.M., Pylypenko Y.I., Kolinets L. B., 2021 a significant share of resources goes to waste, which leads, on the one hand, to environmental pollution, and on the other to reduced potential production and increased cost of production. All these factors affect the level and quality of life, health status of the population negatively [2].

Literature review. Peculiarities of ensuring balanced functioning in different countries of the world are a debatable issue among authors and experts.

The research by Zgurovsky M.Z. [3, 4] is devoted to the analysis of sustainable development in global and regional contexts [5]. The results of modeling of the fault lines between civilizations in the early $21^{\text {st }}$ century in the context of fundamental differences between them are presented. The information on quantitative scores of balanced functioning is presented as thematic maps and profiles of the world countries [3]. The methodology for assessing sustainable functioning as a quaternion functional of quality and security of human life is presented. The level of electronic government growth in Ukraine is studied, recommendations on its implementation in regions are provided. Infographics and analytical profiles are created for each region of Ukraine [4].

Buryk Z. (2016) [6] has explored the theoretical and methodological basis of balanced growth economics in the article 
"Theoretical and methodological basis of sustainable development economics". Also, Buryk Z. (2018) [7] has explored the theoretical aspects of the world evaluation systems of state's balanced growth. Simakhova A., Stukalo N. have analyzed the social approach to the concept of 'green' economy [8]. The key features of sociology of the 'green' economy are explored. The impact of the 'green' development on education, health, social sphere, population wellbeing is explored in the article "Social Dimensions of Green Economy" [8].

The works by Zhukov S. A. are devoted to the definition of the strategy of balanced growth of Ukraine based on the analysis of the national, regional, entrepreneurial levels [9]. Stukalo N., Lytvyn M., Petrushenko Y. have formed a methodological approach to define the country's balanced growth in conditions of world threats in the article "The achievement of the country's sustainable development in the conditions of global threats" $[10]$.

Kozhukhova T.V. has explored the transformation of the world system of financing sustainable growth on the example of different countries in the monograph "Formation and transformation of the global system of financing sustainable development" [11]. Dlugopolsky O. and Kozyuk V. have explored modern trends in the transformation of the welfare state in the context of the quality of institutions and ecological culture in the monograph "The Ecological Dimension of the Welfare State". The authors have proved that the high burden of environmental regulation does not affect the competitiveness of national economies, and environmental education is becoming an important factor in the progress of the new welfare state in the countries with quality institutions [12]. Mantsurov I. has investigated the theoretical aspects of inclusive development in the context of world challenges in the article "Inclusive development as a basis for counteracting modern global challenges" [13].

However, the critical analysis of the researchers' work shows the lack of coverage of problems related, first, to the analysis of the concept of balanced growth of Ukraine in the context of globalization, which led to the choice of research topic, its purpose and relevance.

Purpose. The purpose of the article is to develop the concept of sustainable development of Ukraine in the context of global threats.

Methods. The methods used involve the structural observation of the country's ratings on the key indicators level of the investigated economic, environmental and social components of balanced development. The new methodological approach of defining the environmentally friendly socially oriented economic growth of the country is involved [10], which allowed assessing the balanced functioning of the country, indicators of efficiency and vulnerability to the crisis, which, in turn, adjusts policies to strengthen this functioning.

The research is based on the analysis of the components of integrated indicators and the formation of indicators based on them, which allow assessing the state of balance of socio-economic development of the national economy and determining the directions of corrective policy. In addition, the systematic approach is used to obtain the scientific results, which allowed us to consider the socio-economic development of society as a polysystem phenomenon, comparative analysis, statistical methods - in comparing the situation of Ukraine with other countries, logical analysis - in justifying and developing the concept sustainable development of Ukraine in the context of globalization.

Results. Let us analyze Ukraine's achievements of balanced development: the index of sustainable development, the component of life security that demonstrates global threats and the component of people's quality of life [4]. The life security component integrates all 12 indicators of global threats: conflicts intensity, the information gap, the corruption perception, the spread of global diseases, proliferation, the growing income inequality between people and countries of the earth, the state fragility, the misbalance between biological capacity of the earth and human needs in biosphere, the global warming, the natural disasters, the limited access to drinking-water [10].

The component covers four indices: Social Security Index, Economic Security Index, Environmental Security Index [4]. The main sources for data are the following resources [14]. The values of all indicators of threats are reduced to dimensionless values in the range $[0 ; 1]$, which characterize the vulnerability of the regions of Ukraine to the impact of global threats [15]. The vulnerability value of 0.5 corresponds to the national average of the impact of the global threat, and a value close to 1.0 - the greatest impact.

Since 2014, Ukraine has faced significant social and economic threats to society [4]. Despite the difficult security and development circumstances, large-scale forced migration from the anti-terrorist operation zone, low birth rate and significant public health problems, the country continues its way to the sustainable future [5].

In general, according to the Sustainable Development Index (SDI), Ukraine along with China, India, South Africa and a number of other countries, belongs to the group of countries with a low SDI. This group of countries is characterized by medium and low values of the components of quality and safety of life of sustainable development [4]. So, in 2017, Ukraine ranked $130^{\text {th }}$ in SDI, $80^{\text {th }}$ in the quality of life component and $54^{\text {th }}$ in the security of life component, which demonstrates global threats. [16]

According to the results of data analysis in 2017 [3] Ukraine $(Q=0.476)$ belongs to the cluster of outsider countries with low values of SDI $(0.178<Q<0.486)$. The low value of SDI for Ukraine is due to both the high level of conflict and one of the lowest values of the Index of Economic Dimension ( $I e=0.311$, $134^{\text {th }}$ place out of 137 countries assessed). If we consider the variability of the value of SDI for Ukraine during 2005-2017, we can assume that in the period from 2005 to 2013 the value fluctuated within a rather narrow range $(0.739<Q<0.720)$, the "fall" of the value in 2014 is due to the failure to taking into account the component of human security in the aggregate SDI in connection with the war (according to the terminology of the Heidelberg Institute for International Conflict Studies [17]) in Ukraine.

So, from 2005 to 2013, Ukraine ranked from 62 to 67 among 137 countries assessed on SDI, while since 2014 its positions in the Q rating have shifted to 129-131 places according to the reason mentioned above $[4,16]$.

Regarding the quality of life component, Ukraine ranks $80^{\text {th }}$ in the world in 2017. One group along with Ukraine includes Ecuador and Suriname, Venezuela, Bosnia and Herzegovina, Kazakhstan, and others [4]. The quality of life component in Ukraine is characterized by the degradation of human potential, which is manifested in the depopulation, deteriorating health [18].

During 2005-2017, Ukraine lost about 20 positions in the component of people's quality of life, which can be explained by the decrease in the value of the Economic Dimension Index and the relative position of the country in the ranking of the world's countries according to this index [16].

Fig. 1 presents the structure of the component of global threats of SDI of Ukraine for 2007 and 2017. Analyzing Ukraine's vulnerability to global threats, we stress that compared to 2008 the level of its national security has improved but remains significantly low: from $78^{\text {th }}$ place in 2008 Ukraine rose to $65^{\text {th }}$ in 2013 according to the index of human safety. In terms of the component of life security, Ukraine is in the same group along with the following countries: Ethiopia, Bolivia, Cameroon, and Mozambique. Neighboring ratings to Ukraine are occupied by Sri Lanka and Morocco, which are two and one position higher than the rating of Ukraine, respectively. Zambia's, Georgia's and Vietnam's ranks are lower [19]. According to these statements, it should be noted that the most danger- 


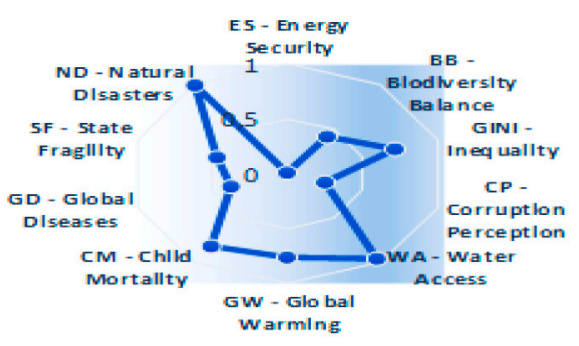

$a$

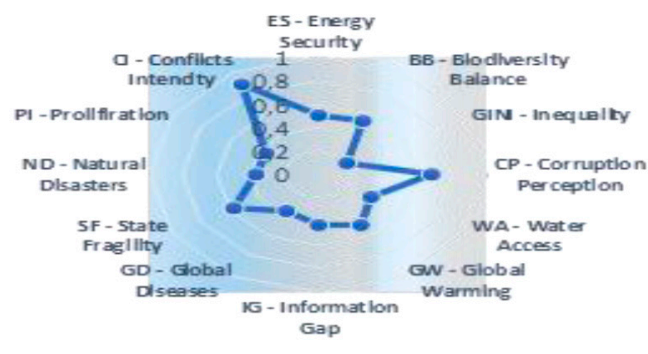

$b$

Fig. 1. Changing structure of global threats to Ukraine's sustainable development under the influence of the global crisis and pandemic [3, 4]

ous challenges to Ukraine remain to be the next ones: one of the highest levels of global diseases in the world, especially STIs and tuberculosis; a very high level of corruption; a low level of energy security; high infant mortality and a high level of state instability [3].

At the present stage, there is a crisis in the ecological situation in Ukraine. The level of man-caused load on the natural environment exceeds the similar indicator of developed countries by $4-5$ times. Investments in environmental construction and financing of environmental activities are declining, which increases the risk of large-scale accidents and catastrophes. The special environmental problem in Ukraine was caused by the Chernobyl accident, which led to radioactive contamination of more than $50000 \mathrm{~km}$ of the territory of Ukraine, where 2994 settlements were located. 26 million people were affected, including 1 million children. Due to the high level of pollution, 180 thousand hectares of arable land and 157 thousand hectares of forest were withdrawn from use. All these factors have led to a crisis in the health of the population. Life expectancy is much lower than in developed countries, the birth rate is declining, and mortality is rising [18]. This is a consequence of unsatisfactory condition of the natural and man-made environment and its most important components; unsatisfactory financial situation of the population; inadequacy of medical care; lack of healthy lifestyle skills in the large part of population [20].

The analysis of the values of aggregate components and indices, as well as some indicators of sustainable development, for Ukraine demonstrates significant differences of this country from the developed countries of the world, countries with high and middle incomes [4]. This statement applies to security, including energy, and issues of corruption, innovation, technological backwardness, combating information challenges and many others [16].

Let us analyze the index of inclusive development of Ukraine. The Inclusive Development Index (IDI) was proposed at the World Economic Forum (WEF) in Davos in 2018 as an alternative to the GDP per capita indicator. It is a composite or aggregate indicator that is proposed to be used for the overall assessment of the state of economic development of the country. At the same time, GDP per capita is considered to be one of the components while calculating the values of IDI [13].

The WEF calculates this index as the average value that averages the value of the set of partial indicators of development inclusiveness (Key Performance Indicators - KPI).
This new composite indicator characterizes the state of the economy more systematically and comprehensively. The environment and the level of social standards, as a result, makes it possible to distribute countries according to the characteristics of human-centered economic development, social standards, environment and equality of society and territories, regardless of the factors that shape their identity. In our opinion, the rating of countries according to the values of the inclusive growth index demonstrates the characteristics of their current development more adequately [13].

According to the WEF methodology, the index averages the values of 12 individual indicators of the country, divided into three groups, each of which combines the characteristics of the economy, environment and model of social behavior of the country [21]

In 2018, the World Economic Forum analyzed the inclusive development of 103 countries, 28 of which belong to the group of developed countries and 75 - to developing countries (as is known, Ukraine also belongs to them). According to the study, Norway, Iceland, Luxembourg, Switzerland and Denmark are the top five countries in terms of inclusive economic growth. The group of developing countries was led by Lithuania, Hungary, Azerbaijan, Latvia and Poland. As we know, according to the classification of the World Bank, Ukraine is part of a group of developing countries, in which the level of economic inclusion ranked $49^{\text {th }}$ and, accordingly, a total of $78^{\text {th }}$ out of 103 countries, the characteristics of which are researched by a team of experts from the World Economic Forum this year. Turkey ranked $16^{\text {th }}$ in the same group, Russia $19^{\text {th }}$, and Moldova $31^{s t}$. Ukraine is followed by Honduras, Pakistan and Tanzania, followed by Jordan, Kyrgyzstan, Ghana and Cameroon. In terms of total scores, Ukraine has the worst performance among all European countries [13].

It should be emphasized that Ukraine is the only one of the 103 countries in the world in which a significant annual decrease in the value of IDI has been observed for five years in a row. It is proved that the negative impact on economic development is growing due to the lack of domestic and foreign investment, as evidenced by the very low value of net savings (only $1 \%$ ). The resumption of investment in fixed assets, which would correspond to the volume of the pre-crisis period, was not achieved in 2014-2017, which significantly limits the opportunities for economic growth and increases the threat of deepening economic crisis.

It is necessary to develop the Concept of Sustainable Development of Ukraine in the Context of Global Threats (Concept) based on the integrated approach. Globalization already requires concrete measures to achieve balanced development of Ukraine, considering environmental, economic, social challenges and threats. The Concept (Fig. 2) will provide an opportunity to gain positive benefits from the process of globalization and avoid negative consequences.

It should be noted that the process of achieving sustainable functioning of Ukraine in the context of global challenges should be consistent and balanced; its strategic goal is the balanced development of the country in the context of globalization.

The main goal of the Concept is to create a new form of government, a new format of public relations and a new economic model capable of effectively overcoming the challenges and threats - inefficient government, insufficient and inefficient resource provision, technological lag in development, limited funding, ongoing armed aggression [22].

The main principles of the Concept are objectivity, reality, compliance with the capabilities of the economic system, adaptability, openness, the same competitive environment. The scale of the Concept is nationwide.

The main objectives of the Concept are the next ones:

1. Social justice - establishing guarantees of equality before the law, ensuring equal opportunities to achieve material, environmental and social well-being, as well as the establishment of 


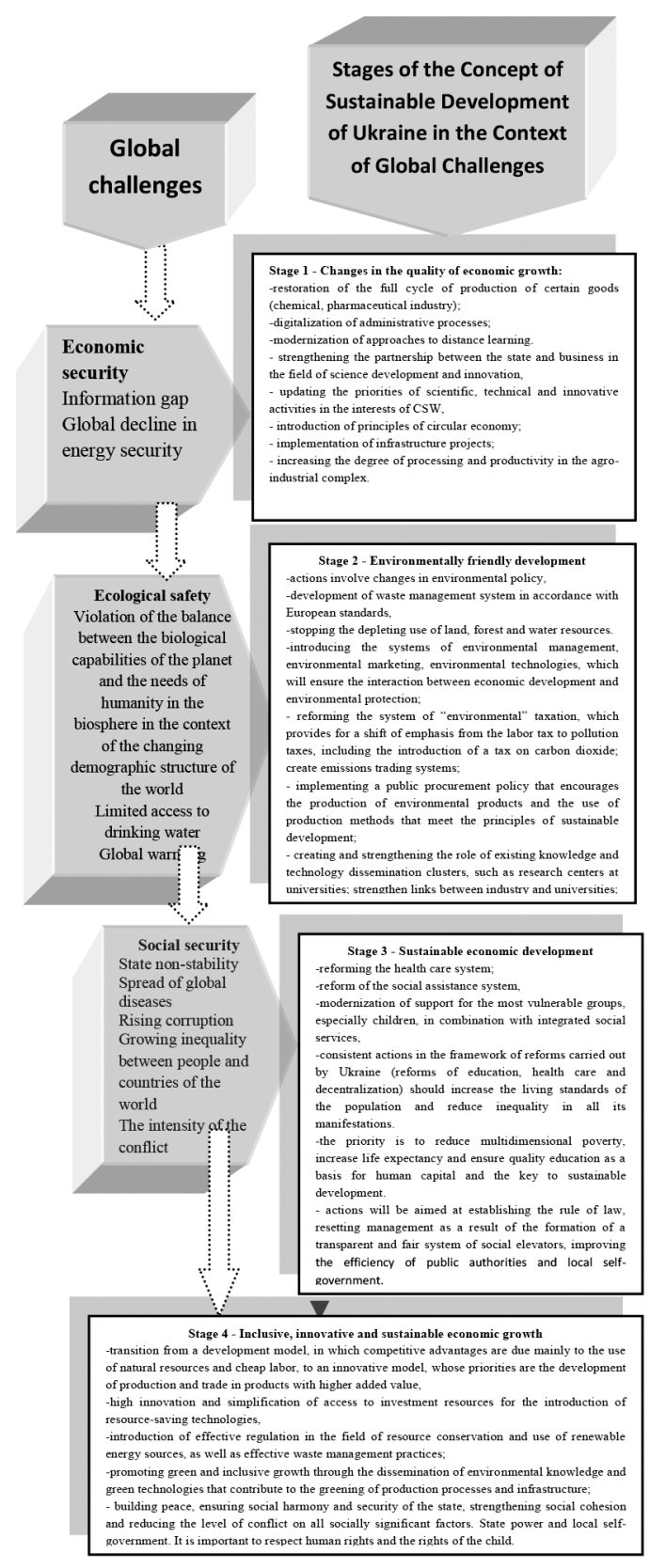

Fig. 2. The Concept of Sustainable Development in Ukraine in the Context of Global Threats [4, 22]

social standards achieved in the European Union, which is an imperative of Ukraine's integration course into the EU.

2. Balanced economic development - providing opportunities, motives and guarantees for the work of citizens, quality of life, functioning of an efficient economy and rational consumption of material resources.

3. Ensuring the high quality of the environment - creating conditions for all citizens to live in a healthy environment with clean air, land, water, protection and restoration of biodiversity.

4. Rational resource use - the creation of a system of guarantees for the rational use of all types of resources based on compliance with the national interests of the country and the preservation of resources for future generations.

5. Demographic stability - the formation of an effective public policy to increase life expectancy and stabilize the population of Ukraine, provide comprehensive support to young families, protection of motherhood and childhood [23].

6. International cooperation - active cooperation with all countries and international organizations to achieve global stability and harmony [24].
The field of application is the economic, social and environmental sphere of Ukraine's activity; the obtained results can be used when devising sustainable development strategies of Ukraine. At the $1^{s t}$ Stage of the Concept, changes are achieved in the quality of economic growth, which reflects the development of the economy based on mainly intensive growth factors. Without economic growth, it is impossible to overcome poverty and improve the living standards of the general population, but it is important not only to improve the economic situation, but also to distribute the results of growth fairly among all segments of the population. Changes are needed in the quality of economic growth, so that it can become innovative, inclusive.

At this stage, it is necessary to restore the full cycle of production of certain goods (chemical, pharmaceutical industry); digitization of administrative processes; modernization of approaches to distance learning, strengthening the partnership between the state and business in the field of science development and innovation, updating the priorities of scientific, technical and innovation activities in the interests of CSW, implementation of the principles of circular economy; implementation of infrastructure projects [22, 23].

At the second stage of the Concept, ecologically safe development is achieved considering global environmental threats.

To implement the tasks of sustainable development, it is necessary to rationalize the territorial organization of nature management, which corresponds to the local natural conditions and natural resource potential of the territory. Equality of the use of natural resources for present and future generations is also important [2]. It is necessary to reorient and balance the sectoral and intrasectoral structures of the economic complex in accordance with the new social and economic conditions [24].

Experience in solving environmental problems is gaining importance in various countries around the world. At the same time, one of the main areas of environmental protection is the organization of safe energy production. The problem of nuclear energy is in the organization of its safety. This is confirmed by the events in Japan in connection with the accident at the Fukushima-1 nuclear power plant.

In the United States, it is the adoption of a law on clean energy and security. It provides for the reduction of greenhouse gas emissions into the atmosphere through the wider use of renewable energy sources:

- in the EU, where the most developed system of environmental regulation, even in a crisis and reduced investment opportunities at the EU summit in Brussels it was decided to increase the energy efficiency of the economy, use-state of energy on renewable sources (air, solar energy) by $20 \%$ by 2020 and reduce carbon dioxide emissions by $20 \%$;

- Sweden intends to become the first country not to use oil as an energy source by 2020 ;

- the Netherlands has developed the concept of "system innovation", which comprehensively solves environmental problems through changes in all policy areas - technological, social, managerial, cultural, and so on;

- Japan has been implementing environmental policy since the 1960-s, and expanded the scope of the Energy Conservation Act in 2009;

- in China, which ranked first in the world in terms of carbon emissions, in recent years, laws and programs have been adopted to improve the environmental situation. For example, it is planned to receive $15 \%$ of energy from renewable sources by 2020 , and to reduce carbon dioxide emissions per unit of GDP by $40-45 \%$ [23].

Active innovation is bringing its results. According to environmental policy, $75 \%$ of all air power generation capacity is concentrated in the EU. In Finland today, the profit of the export of innovative energy technologies is twice the cost of oil imports. In Austria, the district of Güssing switched to self-sufficiency in energy using local renewable energy sources, which help to im- 
prove living standards and at the same time reduce carbon emissions by $90 \%$. In Germany, the project "United Power Plant" was implemented, which combined 36 air, solar, hydraulic plants, as well as equipment running on biomass into a single national system [20]. This allowed reducing fluctuations in energy supply and providing it entirely through renewable sources. Ukraine is also trying to organize an environmentally friendly economy and produce environmentally friendly products, but they still need further development and improvement [25].

Because the scale of modern world production and consumption has led to a catastrophic imbalance of natural and social systems, every national economy must have an environmentally friendly orientation. International experience of economic activity shows that effective measures to achieve this goal can be considered:

- formation of an effective environmental policy of the country;

- improvement of the legislative and regulatory framework for environmental protection and the functioning of the environmentally sound economy;

- implementation of structural ecologically oriented restructuring of the economy;

- creation of branch research centers and funds for creation of scientifically substantiated programs of ecological innovations; development of concepts of "systemic innovations", which comprehensively solve environmental problems through changes in all areas of policy - technological, social, managerial, cultural, and so on;

- organization of energy security (energy sector is becoming the main component of a new environmentally oriented policy; development and implementation of alternative and renewable energy sources);

- creation of environmentally friendly production; development of resource- and energy-saving and waste-free technologies, use of secondary materials;

- stimulating the development of ecological innovations as a tool to increase production efficiency and to obtain competitive advantages on this basis;

- formation of the ecological market (market of ecologically clean products) and, for this purpose, implementation of tax and budgetary reforms, dissemination of the practice of nature protection public procurement, elimination of trade barriers on the way of ecological goods and services [2].

International experience demonstrates that the greening of the economy is a priority tool for sustainable development of both the individual state and the world, so the development and implementation of eco-innovation in all areas of activity is essential for the existence of the human community [23].

At the $3^{r d}$ stage of the Concept, sustainable development is achieved considering economic, social and environmental global threats, which provides for high growth rates of the economy and social standards, resource-saving and environmentally friendly production, and competitive economy.

Economic reforms are necessary for the transition to the principles of sustainable development, the strategic direction of which should be to strengthen their socio-environmental orientation, that is implemented through the solution of the following main tasks: improving socio-economic and production conditions; increasing real incomes of the population on the basis of state regulation of wages and pensions; growth of educational and cultural level of the population; creating favorable conditions for health, motherhood and childhood [23].

To achieve sustainable development of Ukraine considering global threats, it is necessary to [22]: reform the health care system; reform of the social assistance system, modernize the support for the most vulnerable groups, especially children, in combination with integrated social services, carry out consistent actions within the framework of reforms in Ukraine (education reforms, health care and decentralization systems) [23].

At the $4^{\text {th }}$ stage of the Concept, it is necessary to achieve inclusive, innovative and sustainable economic growth, which provides high and stable rates of economic and social development, a high level of well-being of members of society and territories, regardless of the factors that create their identity, population.

To boost the economy, it is necessary to increase the share of investment in GDP at least to the level of developed countries (25-30\%). Only under these conditions it is possible to create opportunities for advanced playback. In fast-growing countries, the share of investment in GDP reaches $40 \%$ (as, for example, in China, which has been providing an annual GDP growth of $10 \%$ for 30 years). To achieve inclusive economic growth it is necessary to eliminate distortions in macroeconomic reproduction processes, which means to ensure optimal proportions between investment and consumption; to streamline the ratio between the growth rate of wages and the growth rate of labor productivity, the rate of renewal and disposal of fixed assets; to keep inflation at a moderate level, to prevent deflationary processes; to stimulate domestic consumption through the growth of effective household demand, and so on. The identified trends in the national economy of Ukraine indicate the strengthening of macroeconomic, financial, investment, production and foreign economic threats and risks, which significantly worsen the prospects for recovery and economic growth and indicate the existence of a critical situation with signs of pathology and toxicity [13]. There is an objective need to replace the current model with another (more effective and progressive), namely - strategically defined, institutionally oriented and innovation-oriented. The most difficult issue in the formation of directions for the implementation of a new model of development is to determine the priorities of economic development and the formation of a new institutional mechanism [13].

Conclusion. The Concept of Sustainable Development of Ukraine in the Context of Global Threats based on an integrated approach has been developed. Globalization already requires concrete measures to achieve balanced development of Ukraine, considering environmental, economic, social challenges and threats. The concept will provide an opportunity to reap the benefits of globalization and avoid negative consequences. The main goal of the concept is to create a new form of government, a new format of public relations and a new economic model capable of effectively overcoming the challenges and threats - inefficient public administration, insufficient and inefficient resources, technological lag in development, limited funding, ongoing armed aggression.

The implementation of the Concept will affect the formation of the basis for Ukraine's integration into the world space in accordance with the objective trends of globalization.

\section{References.}

1. Transforming our world: the 2030 Agenda for Sustainable Development (2020). Retrieved from https://sdgs.un.org/2030agenda.

2. Shinkaruk, L. (2012). World economic disproportion: features, trends, impact on the economy of Ukraine: a scientific report, 152. Retrieved from http://ief.org.ua/docs/sr/dop_Shynkaruk_2012.pdf.

3. Zgurovsky, M. (2019). Sustainable Development Analysis: Global and Regional Contexts, Part.1. Global Analysis of Quality and Security of Life. Retrieved from http://wdc.org.ua/sites/default/files/SD2019P1-FULL-EN.pdf.

4. Zgurovsky, M. (2019). Sustainable Development Analysis :Global and Regional Contexts. Part 2. Ukraine in Sustainable Development Indicators. Retrieved from http://wdc.org.ua/sites/default/files/SD2019P2-FULL-EN.pdf.

5. Zgurovsky, M. (2018). Foresight 2018: systemic world conflicts and global forecast for the $21^{\text {st }}$ century. Retrieved from http://wdc.org.ua/ sites/default/files/WDC-IASA-FORESIGHT-2018-HCA.pdf

6. Buryk, Z. (2016). Theoretical and methodological basic of sustainable development economics. International Journal of Economics and Society, 6(2), 97-107.

7. Buryk, Z. (2018). World evaluation systems of the sustainable development of state. European Cooperation: Scientific Approaches and Applied Technologies, 1(32), 69-78. 
8. Stukalo, N., \& Simakhova, A. (2019). Social Dimensions of Green Economy. Filosofija, Sociologija, 30(2), 91-99. https://doi. org/10.6001/fil-soc.v30i2.4015.

9. Zhukov, S., \& Malinoshevska, K. (2018). Strategy of sustainable development of Ukraine: analysis of national, regional and entrepreneurial levels of support. Economic Management: Theory and Practice, 12-20.

10. Stukalo, N., Lytvyn, M., Petrushenko, Y., \& Omelchenko, Y. (2020). The achievement of the country's sustainable development in the conditions of global threats. International Symposium of Earth, Energy, Environmental Science and Sustainable Development, JESSD. Indonesia, 211, 01029. https://doi.org/10.1051/e3sconf/202021101029. 11. Kozhukhova, T. (2017). Formation and transformation of the global system of financing sustainable development: monograph.

12. Kozyuk, V., Dlugopolsky, O., Gaida, Y., Szymanska, O., \& Vozny, K. (2019). Ecological dimension of the welfare state: monograph.

13. Mantsurov, I. (2018). Inclusive development as a basis for counteracting the global challenges of today. Economy of Ukraine, 10(683), 71-87.

14. State Statistics Service of Ukraine (2020). Retrieved from http:// www.ukrstat.gov.ua/.

15. Ministry of Ecology and Natural Resources of Ukraine (2020). Retrieved from https://menr.gov.ua.

16. Sustainable Development Modeling (2020). Retrieved from http:// sdi.wdc.org.ua/global/.

17. Heidelberg Institute for International Conflict Research (n.d.). Conflict Barometers 2011-2017. Retrieved from https://hiik.de/ download/conflict-barometers-2011-2017/?lang=en\&wpdmdl=3491 $\&$ refresh $=5$ ceaf75171c521558902609.

18. Kolesnikova-Steinrud, O. (2016). Human Development Index (HDI) and possible ways to increase its level in Ukraine development. Retrieved from http://dspace.snu.edu.ua:8080/jspui/bitstream/123456789/505/12/ dudka.pdf.

19. Global Wage Report 2018-2019 (2019). Retrieved from http://cite. gov.pt/pt/destaques/complementosDestqs2/WAGE_REPORT 2018 2019.pdf.

20. Shyrynya, J. (n.d.). Problems of sustainable development in Ukraine: ecological aspect. Retrieved from www.repository.hneu.edu.ua.

21. Tymoshenko, O. (2016). Economic security of the national economy in the context of globalization: monograph.

22. Voluntary national review of the Sustainable Development Goals (2020). Retrieved from https://sustainabledevelopment.un.org/content/documents/26295VNR_2020_Ukraine_Report.pdf.

23. Markova, N. (2013). Application of European experience in the formation of sustainable development in Ukraine. Investments: practice and experience, $1,115-118$.

24. Brizhan, I. (2013). Conditions and factors of Ukraine's transition to the model of sustainable development. Bulletin of the Poltava State Agrarian Academy, 1, 128-133.

25. European Commission. Eurostat. Statistics. Environment (2018). Retrieved from http://epp.eurostat.ec.europa.eu/portal/page/portal/ environment/introduction.

\section{Концепція сталого розвитку України в контексті глобальних загроз}

\section{Н. В. Стукало ${ }^{1}$, М. В. Литвин ${ }^{2}$ Ю. М. Петрушенко ${ }^{3}$,} Ю. І. Пилипенко ${ }^{2}$, Л. Б. Колінеиь ${ }^{4}$

1 - Національне агентство із забезпечення якості вищої освіти, м. Київ, Україна

2 - Національний технічний університет «Дніпровська політехніка», м. Дніпро, Україна, e-mail: maryna_lytvyn@ $\underline{\text { ukr.net }}$

3 - Сумський державний університет, м. Суми, Україна 4 - Західноукраїнський національний університет, м. Тернопіль, Україна

Мета. Створення концепції сталого розвитку України в контексті глобальних загроз
Методика. Дослідження базується на основі аналізу складових інтегральних показників і формуванні на їхній основі індикаторів, що дозволяють оцінити стан збалансованості соціально-економічного розвитку національної економіки та визначати напрями проведення коригуючої політики. Поряд з цим для отримання наукових результатів було використано системний підхід, що дозволив розглянути соціально-економічний розвиток суспільства як полісистемне явище, компаративний аналіз, методи статистики - при проведенні порівнянь становища України з іншими країнами світу, логічного аналізу при обгрунтуванні й розробці концепції сталого зрозвитку України в контексті глобалізації.

Результати. Розроблена концепція сталого розвитку України, що спрямована на формування нового формату соціальних відносин і нової моделі економіки 3 метою підвищення стійкості національної економіки до глобальних загроз. Проаналізовані складові індексу сталого розвитку та здійснено порівняльний аналіз компонентів глобальних загроз для України та інших країн світу. Доведено, що для України найнебезпечнішими викликами на сучасному етапі є високий рівень поширення захворюваності серед населення, висока дитяча смертність, корумпованість, низький рівень енергетичної безпеки та неефективне державне управління. Обгрунтовано, що основною метою реалізації концепції сталого розвитку України є формування умов для подолання існуючих загроз. Це потребує створення нової форми державного управління, нового формату зав’язків із громадськістю та нової економічної моделі. Запропоновані напрями досягнення в Україні основних цілей сталого розвитку: соціальної справедливості, збалансованості економічного зростання, забезпечення високої якості навколишнього середовища, раціонального використання ресурсів, демографічної стабільності та взаємовигідного міжнародного співробітництва.

Наукова новизна. Авторська концепція сталого розвитку України грунтується на забезпеченні здатності національної економіки скористатися позитивним екстернальним ефектом глобалізації та за рахунок цього знизити іiі негативний вплив на суспільство. Встановлена етапність. Обгрунтована необхідність запровадження послідовних і взаємопов'язаних заходів, спрямованих на зміну якості соціально-економічного розвитку країни на основі задіяння переважно інтенсивних факторів економічного зростання, упровадження екологобезпечних методів ведення господарської діяльності, забезпечення реалізації принципів сталого розвитку в контексті подолання багатовимірної бідності, зростання середньої тривалості життя, формування ефективної системи соціальної допомоги та охорони здоров'я. Доведено, що впровадження зазначених заходів забезпечить формування нового формату соціальних відносин і нової моделі економіки, а також дозволить досягти цілей сталого розвитку.

Практична значимість. Результати дослідження можуть бути використані урядами держав у проведенні політики сприяння сталому розвитку, а також компаніями, що здійснюють свою економічну діяльність у глобалізованому просторі.

Ключові слова: сталий розвиток, глобальні загрози, глобалізація

Recommended for publication by $Y$. V. Chirichenko, Doctor of Economic Sciences. The manuscript was submitted 09.01.21. 